\title{
Effect of Aluminium Chloride on Sexual Efficiency in Adult Male Rats
}

\author{
Entissar, M. Abdul-Rasoul* ${ }^{*} \quad$ Nathem, A. Hassan* \\ Department of Physiology / College of Veterinary Medicine \\ University of Mosul
}

Karam, H. Al-Mallah**

Department of Pathology / College of Veterinary Medicine University of Mosul

Received
r/ $/ 0 \curlyvee / 200 \wedge$
Accepted

$01 / 12$ / 2008

\section{الخلاصة}

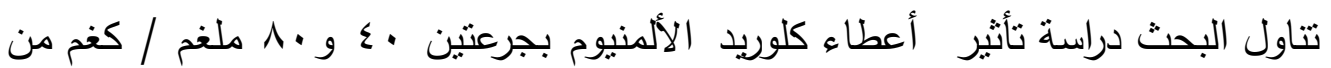

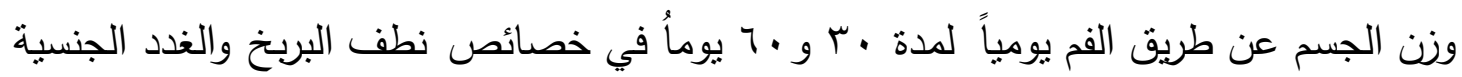

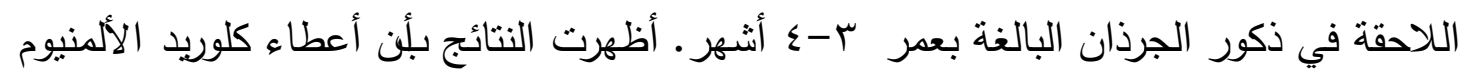

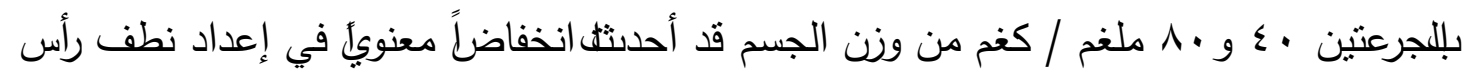

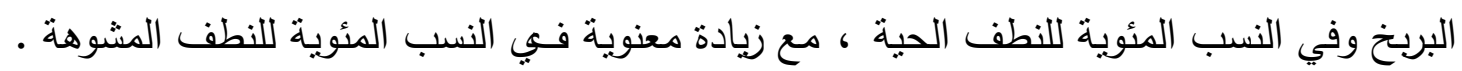
وانخفاض معنوي في معدل وزن الجسم، وزن جسم البربخ، الخصية وغدة البروستات في الجرذان

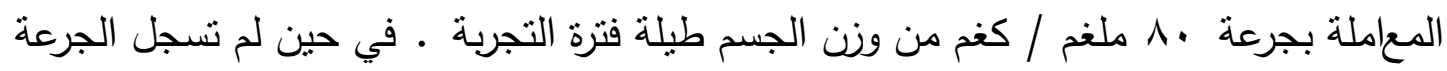

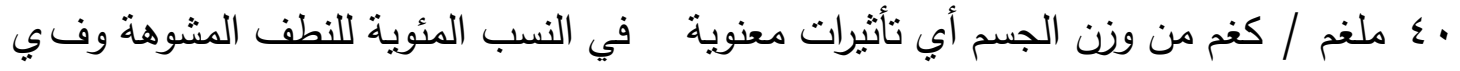

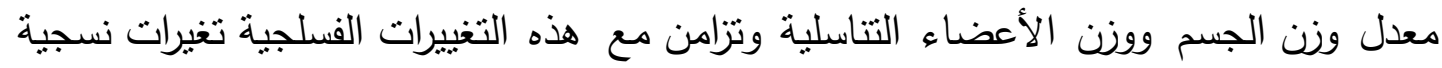

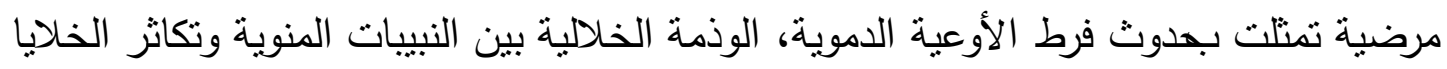
الخلالية رافقه فرط التنسج و تتكس ونخر وانسلاخ في الخلايا الظهارية للنبييات المنوية ـ يستتتج من النتائج أن كلوريد الألمنيوم له تأثثرات سلبية في الكفاءة التتاسلية لذكور الجرذان الباليانة.

$\dagger$ corresponding auther; E-mail : ent_man1971@yahoo.com

ABSTRACT 
The study was conducted to reveal the effect of oral administration of aluminium chloride on spermatogenesis and accessory sex organs in adult male rats. Aluminium chloride was administrated by oral intubation daily with two doses 40 and $80 \mathrm{mg} / \mathrm{kg}$. body weight for periods 30 and 60 days for each. The results showed that aluminium chloride at both doses caused a significant reduction in sperm counts and the percentage of live sperm, with a significant increased in the percentage of morphologically abnormal sperm, and a significant reduction in averages of body weights, head epididymis, testis and prostate gland weights in rats treated with aluminium chloride at dose $80 \mathrm{mg} / \mathrm{kg}$. body weight during the experimental period. While aluminium chloride at dose $40 \mathrm{mg} / \mathrm{kg}$. body weight had no changes in the percentage of the morphologically abnormal sperm and in the body weight, testis and accessory reproductive organs weights. Synchronized with the physiological changes, histological alterations represented by vascular hyperemia, interstitial edema, multiplication of Leydig cells, coagulative necrosis, hyperplasia and sloughing of seminiferous tubular epithelium. The results concluded that administration of aluminium chloride to adult male rats would cause adverse effects on sexual efficiency.

Key words : Aluminium chloride, spermatogenesis, rats.

\section{INTRODUCTION}

Aluminium (Al) is one of the most common elements in the earth's crust (1).It is a widely distributed in the environment and is extensively used in modern daily life. Aluminium enters into the body from the environment and from diet (2). Al-containing diet is mainly corn, yellow cheese, salts, herbs, spices, tea, (3) and cosmetics such as antiperspirant and deodorant preparation (4). Moreover, it is incorporated in some medications such as antacids, buffered aspirin, anti_diarrheal products, vaccine and allergen injection $(5,6,7)$, and it is used as acomponent of veterinary medicine, glues and disinfectants (8). Al. sulphate is extensively added as a coagulant aget during the purification process of drinking water (9). Recently increased attention is being paid to aluminium compound due to its serious effects on the central nervous system (10), energy metabolism and hematology $(11,12)$, fertility and reproduction $(13,14)$, embryotoxicity and teratogenic potent $(15)$.

Aluminium chloride induced reproductive toxicity and exerted a signifigant adverse effect on the steroidogenesis (16) and caused deterioration in sperm motility and viability, enhancement of free radicals and alterations in enzyme activities on rabbit sperm (17), with alterations in the metabolism of testis, epididymis and vas deferens that led to poor sperm motility and reduction in fertility rate in mice treated with aluminium chloride $(400 \mathrm{mg} / \mathrm{kg}$ body weight) for 15 days or in chronic treatment at dose $(200 \mathrm{mg} / \mathrm{kg}$ body weight) for 60 days $(18,19)$. Liobet et 
al.,(20) observed that some histological changes including necrosis of spermatocytes and spermatids in the testis of male mice treated with aluminium nitrate, and degeneration in structure of spermatogenesis and formation of giant cells in mice testis treated with aluminium chloride(21), severe damage within seminiferous tubules and vascular degeneration on spermatogonic and Sertoli cells cytoplasm(22).

Furthermore reduced testis acetylcholinesterase activity presumably plays an important role in aluminium chloride (23).

The purpose of the present study is to evaluate the adverse effects on spermatogenesis of aluminium chloride in adult male rats.

\section{Animals:}

\section{MATERIALS AND METHODS}

Adult male Albino rats (3-4 months age), weighing (190-215g) in this study provided by the animal house unit in the college of Veterinary Medicine at Mosul University. Animals were housed in polypropylene cages under standard husbandary condition (12hr light/dark cycle: $\left.25 \pm 3 C^{\circ}\right)$. The rats were supplied diet and water ad libitum.

\section{Test chemical :}

Aluminium chloride $\left(\mathrm{AlCl}_{3}\right)$ was obtained from (BDH chemicals, Ltd., Poole, England). It was administrated aqueous solution by using distilled water.

\section{Experimental design :}

36 male rats of proven fertility were randomly divided into 6 groups of 6 rats each. All groups were given orally by gavage tube.

Group 1: rats served as control and received the vehicle $(0.5 \mathrm{ml}$.distilled water / day) for 30 days.

Group 2: rats received aluminium chloride $(40 \mathrm{mg} / \mathrm{kg}$. body weight $/$ day $)$ for 30 days.

Group 3: rats received aluminium chloride $(80 \mathrm{mg} / \mathrm{kg}$. body weight/day) for 30 days.

Group 4: rats served as control and received the vehicle $(0.5 \mathrm{ml}$.distilled water/day) for 60 days.

Group 5: rats received aluminium chloride ( $40 \mathrm{mg} / \mathrm{kg}$. body weight $/ \mathrm{day})$ for 60 days.

Group 6: rats received aluminium chloride $(80 \mathrm{mg} / \mathrm{kg}$. body weight/day) for 60 days.

\section{Sample collection and analysis:}

The body weight of each animal was recorded initially and then at the time of autopsy. On day 31 and 61 animals were sacrified under mild either anesthesia (24). The testes and accessory sex organs (epididymis, seminal vesicles and prostate gland) were dissected out, cleared and weighed. Epididymis was dissected out, sectioned and immediately the 
content of the head of epididymis was squeezed gently in a clean watch glass contained $9.8 \mathrm{ml}$. buffer formalin with $0.1 \mathrm{ml}$. eosin stain $(5 \%)$. This was used for counting the sperm using hemocytometric technique $(25,26)$. The percentage of live and morphologically abnormal sperms were counted in smear prepared from epididymal tail content by using eosin-nigrosin stain diluted with $3 \%$ sodium citrate (27).

\section{Histological analysis :}

Testes were fixed in Bouin`s fluid, passed through ascending series of ethanol and then through xylene and embedded in paraffin wax. Tissues were sectioned at the thickness of $2-3 \mu \mathrm{m}$ and stain with hematoxillin and eosin (28).

\section{Statistical Analysis :}

The results were expressed as mean \pm SE. Our data were analyzed statistically using one and two_ways analysis of variance (Anova). Group differences were determined using Duncan multiple range test. Differences were considered significant when $(\mathrm{P} \leq 0.05)(29)$.

\section{RESULTS}

\section{The effects of aluminium chloride on body weight in rats.}

The present investigation revealed that the B.W. in the group treated with $\mathrm{AlCl}_{3}$ at dose $80 \mathrm{mg} / \mathrm{kg} . \mathrm{B} . \mathrm{W}$. showed a significantly $(\mathrm{P} \leq 0.05)$ decline at days 30 and 60comparison to control and $\mathrm{AlCl}_{3}-$ treated group at dose $40 \mathrm{mg} / \mathrm{kg} . \mathrm{B}$.W. While body weight show no signifigantly change in $\mathrm{AlCl}_{3}$-treated group at dose $40 \mathrm{mg} / \mathrm{kg} . \mathrm{B} . W$. as compared with the control group during the experimental period (table 1).

Table (1): effect of aluminium chloride on body weight in rats.

\begin{tabular}{|c|c|c|}
\hline Treatment groups & Initial body weight (g) & Final body weight (g) \\
\hline $\begin{array}{c}\text { Control } \\
(0.5 \mathrm{ml} \text {. D.W. }) \text { for } 30 \text { days }\end{array}$ & $195 \pm 6.8 \mathrm{a}$ & $230 \pm 8.2 \mathrm{a}$ \\
\hline $\begin{array}{c}\mathrm{AlCl}_{3}-\text { treated } \\
(40 \mathrm{mg} / \mathrm{kg} . \text { B.W. }) \text { for 30days })\end{array}$ & $183 \pm 5.8 \mathrm{a}$ & $224 \pm 5.4 \mathrm{a}$ \\
\hline $\begin{array}{c}\mathrm{AlCl}_{\mathbf{3}}-\text { treated } \\
(80 \mathrm{mg} / \mathrm{kg} . \text { B.W. }) \text { for } 30 \text { days }\end{array}$ & $188 \pm 15.8 \mathrm{a}$ & $217 \pm 7.1 \mathrm{~b}$ \\
\hline $\begin{array}{c}\text { Control } \\
(0.5 \mathrm{ml} . \mathrm{D} . \mathrm{W} . \text { for } 60 \text { days })\end{array}$ & $200 \pm 4.3 \mathrm{a}$ & $270 \pm 4.9 \mathrm{a}$ \\
\hline $\begin{array}{c}\mathrm{AlCl}_{\mathbf{3}}-\text { treated } \\
(40 \mathrm{mg} / \mathrm{kg} . \text { B.W. }) \text { for } 60 \text { days }\end{array}$ & $211 \pm 10 \mathrm{a}$ & $260 \pm 6.6 a$ \\
\hline $\begin{array}{c}\mathbf{A l C l}_{\mathbf{3}} \text {-treated } \\
(80 \mathrm{mg} / \mathrm{kg} . \text { B.W. }) \text { for } 60 \text { days }\end{array}$ & $209 \pm 5.2 \mathrm{a}$ & $247 \pm 5.1 \mathrm{~b}$ \\
\hline
\end{tabular}

Number of animals 6 rats/ group.

Values were expressed as means $\pm \mathrm{SE}$.

Values with different letters are significantly different $(\mathbf{P} \leq \mathbf{0 . 0 5})$. 
The effects of aluminium chloride on testes and accessory sex organs weight in rats.

The results described in table (2) the oral administration of rats with $\mathrm{AlCl}_{3} 40 \mathrm{mg} / \mathrm{kg} \mathrm{B}$.W. had no apparent significantly effective in average weight of testis and accessory sex organs epididymal (head, body and tail), seminal vesicle and prostate gland during the experimental period as compared with control group. While $\mathrm{AlCl}_{3}$-treated groups at dose $80 \mathrm{mg} / \mathrm{kg}$. B.W. produced a significant $(\mathrm{P} \leq 0.05)$ decrease in the weight of epididymal head, testis and prostate gland during the experimental period as compared with control group. While no significant changes were obtained in weight of epididymal (body and tail) and seminal vesicle as compared with control groups and with $\mathrm{AlCl}_{3}$-treated groups at dose $40 \mathrm{mg} / \mathrm{kg}$. B.W. during the experimental period. $\mathrm{AlCl}_{3}-$ treated groups at dose $80 \mathrm{mg} / \mathrm{kg}$. B.W. more effective on weights of the testes and prostate gland at day 60 as compared with day 30 and with $\mathrm{AlCl}_{3}$-treated group at dose $40 \mathrm{mg} / \mathrm{kg}$. B.W. at day 60 of treatment.

Table (2) : effect of aluminium chloride on testis and accessory sex organs weights in rats.

\begin{tabular}{|c|c|c|c|c|c|c|}
\hline \multirow{2}{*}{$\begin{array}{l}\text { Treatment } \\
\text { groups }\end{array}$} & \multicolumn{3}{|c|}{$\begin{array}{c}\text { Epididymis weight } \\
(\mathrm{mg} / 100 \mathrm{gB} . \mathrm{W})\end{array}$} & \multirow{2}{*}{$\begin{array}{c}\text { Testis } \\
\text { weight } \\
\text { (mg/100g } \\
\text { B.W.) }\end{array}$} & \multirow{2}{*}{$\begin{array}{c}\text { Seminal } \\
\text { vesicle } \\
\text { (mg /100g } \\
\text { B.W.) }\end{array}$} & \multirow{2}{*}{$\begin{array}{c}\text { Prostate } \\
\text { gland } \\
(\mathrm{mg} / 100 \mathrm{~g} \\
\text { B.W.) }\end{array}$} \\
\hline & Head & Body & Tail & & & \\
\hline $\begin{array}{l}\text { Control ( }(0.5 \mathrm{ml} \text { of } \\
\text { D.W. for } 30 \text { days) } \\
\end{array}$ & $\begin{array}{c}81 \pm 4.2 \\
\mathrm{a} \\
\end{array}$ & $\begin{array}{c}13.5 \pm 1.4 \\
\mathrm{a} \\
\end{array}$ & $\begin{array}{c}70 \pm 2 \\
\mathrm{a} \\
\end{array}$ & $\begin{array}{c}550 \pm 23 \\
\mathrm{a} \\
\end{array}$ & $\begin{array}{c}97 \pm 20 \\
\mathrm{a} \\
\end{array}$ & $\begin{array}{c}491 \pm 32 \\
\mathrm{a} \\
\end{array}$ \\
\hline \begin{tabular}{|l|l}
$\mathrm{AlCl}_{3}(40 \mathrm{mg} / \mathrm{kg}$ \\
B.W. for 30 days $)$ \\
\end{tabular} & $\begin{array}{c}80.5 \pm 1.5 \\
\mathrm{a} \\
\end{array}$ & $\begin{array}{c}14.3 \pm 1.1 \\
\mathrm{a} \\
\end{array}$ & $\begin{array}{c}63 \pm 3 \\
\mathrm{a}\end{array}$ & $\begin{array}{c}560 \pm 24 \\
\mathrm{a} \\
\end{array}$ & $\begin{array}{c}111 \pm 12 \\
\mathrm{a}\end{array}$ & $\begin{array}{c}485 \pm 42 \\
a b \\
\end{array}$ \\
\hline \begin{tabular}{|l|l}
$\mathrm{AlCl}_{3}(80 \mathrm{mg} / \mathrm{kg}$ \\
$\mathrm{B}$. . for 30 days $)$ \\
\end{tabular} & $\begin{array}{c}65.4 \pm 6.5 \\
\mathrm{~b}\end{array}$ & $\begin{array}{c}14.2 \pm 1 \\
\mathrm{a}\end{array}$ & $\begin{array}{c}68 \pm 2 \\
\mathrm{a}\end{array}$ & $\begin{array}{c}447^{ \pm 23} \\
\mathrm{~b}\end{array}$ & $\begin{array}{c}93.7 \pm 6 \\
\mathrm{a} \\
\end{array}$ & $\begin{array}{c}471^{ \pm} \pm 40 \\
\mathrm{~b}\end{array}$ \\
\hline $\begin{array}{l}\text { Control }(0.5 \mathrm{ml} \text { of } \\
\text { D.W. for } 60 \text { days }) \\
\end{array}$ & $\begin{array}{c}85 \pm 3.1 \\
\mathrm{a} \\
\end{array}$ & $\begin{array}{c}13.9 \pm 1 \\
\mathrm{a} \\
\end{array}$ & $\begin{array}{c}67 \pm 2 \\
\mathrm{a} \\
\end{array}$ & $\begin{array}{c}530 \pm 17 \\
\mathrm{ab}\end{array}$ & $\begin{array}{c}120 \pm 2 \\
\mathrm{a}\end{array}$ & $\begin{array}{c}510 \pm 13 \\
a \\
\end{array}$ \\
\hline \begin{tabular}{|l|}
$\mathrm{AlCl}_{3}(40 \mathrm{mg} / \mathrm{kg}$ \\
B.W. for 60 days $)$ \\
\end{tabular} & $\begin{array}{c}73 \pm 0.6 \\
a b\end{array}$ & $\begin{array}{c}12.2 \pm 2 \\
\mathrm{a}\end{array}$ & $\begin{array}{c}62 \pm 3 \\
\mathrm{a} \\
\end{array}$ & $\begin{array}{c}465 \pm 27 \\
\mathrm{~b}\end{array}$ & $\begin{array}{c}99 \pm 10 \\
\mathrm{a} \\
\end{array}$ & $\begin{array}{c}480 \pm 34 \\
a b\end{array}$ \\
\hline $\begin{array}{l}\mathrm{AlCl}_{3}(80 \mathrm{mg} / \mathrm{kg} \\
\mathrm{B} . \text {. for } 60 \text { days }) \\
\end{array}$ & $\begin{array}{c}68 \pm 3.7 \\
\mathrm{~b}\end{array}$ & $\begin{array}{c}12.6 \pm 1 \\
\mathrm{a} \\
\end{array}$ & $\begin{array}{c}65 \pm 2 \\
\mathrm{a} \\
\end{array}$ & $\begin{array}{c}388 \pm 17 \\
\mathrm{c}\end{array}$ & $\begin{array}{c}105 \pm 9 \\
\mathrm{a} \\
\end{array}$ & $\begin{array}{c}395 \pm 20 \\
\mathrm{c} \\
\end{array}$ \\
\hline
\end{tabular}

Number of animals 6 rats/ group.

Values were expressed as means $\pm \mathrm{SE}$.

Values with different letters are significantly different $(\mathrm{P} \leq 0.05)$.

\section{The effects of aluminium chloride on sperm characteristics in rats.}

Treatment of rats with $\mathrm{AlCl}_{3}$ produced significant changes in sperm characterstics as shown in table (3).

The groups treated with $\mathrm{AlCl}_{3}$ at doses 40 and $80 \mathrm{mg} / \mathrm{kg} . \mathrm{B} . \mathrm{W}$. caused a significant $(\mathrm{P} \leq 0.05)$ decrease in both sperm counts and live sperm percentage during the experimental period, and $\mathrm{AlCl}_{3}$-treated groups at dose $80 \mathrm{mg} / \mathrm{kg} . \mathrm{B} . \mathrm{W}$. the more effective it is observed a 
significantly $(\mathrm{P} \leq 0.05)$ decreased in sperm counts and live sperm percentage accompained a significant $(\mathrm{P} \leq 0.05)$ increase in the percentage of morphologically of abnormal sperm as compared with control group during the experimental period (Fig 1,2).

Table (3) : effects of aluminium chloride on sperm characteristics in rats.

\begin{tabular}{|c|c|c|c|}
\hline $\begin{array}{l}\text { Treatment } \\
\text { groups }\end{array}$ & $\begin{array}{l}\text { Sperm counts } \\
\text { sperm } \times 10^{6} / \mathrm{ml}\end{array}$ & Live sperm \% & $\begin{array}{l}\text { Abnormal } \\
\text { sperm \% }\end{array}$ \\
\hline $\begin{array}{c}\text { Control group } \\
(0.5 \mathrm{ml} \text { of D.W. for } 30 \text { days })\end{array}$ & $2.85 \pm 0.1 \mathrm{a}$ & $83 \pm 2.74 \mathrm{a}$ & $10.8 \pm 1.6 \mathrm{~b}$ \\
\hline $\begin{array}{c}\mathbf{A l C l}_{\mathbf{3}} \text {-treated group } \\
(40 \mathrm{mg} / \mathrm{kg} . \text { B.W. for 30days })\end{array}$ & $1.71 \pm 0.2 b$ & $69 \pm 2.39 b$ & $17 \pm 0.9 \mathrm{ab}$ \\
\hline $\begin{array}{c}\mathbf{A l C l}_{\mathbf{3}} \text {-treated group } \\
(80 \mathrm{mg} / \mathrm{kg} . \mathrm{B} . \mathrm{W} \text {. for 30days })\end{array}$ & $0.95 \pm 0.1 \mathrm{c}$ & $42 \pm 6 \mathrm{~cd}$ & $19 \pm 3.3 \mathrm{a}$ \\
\hline $\begin{array}{c}\text { Control group } \\
(0.5 \mathrm{ml} \text { of D.W. for } 60 \text { days })\end{array}$ & $2.5 \pm 0.3 \mathrm{a}$ & $81 \pm 4.3 \mathrm{a}$ & $12 \pm 3.4 \mathrm{~b}$ \\
\hline $\begin{array}{c}\mathbf{A l C l}_{\mathbf{3}} \text {-treated group } \\
(40 \mathrm{mg} / \mathrm{kg} . \text { B.W. for 60days })\end{array}$ & $1.54 \pm 0.14 b$ & $53 \pm 5.4 \mathrm{c}$ & $16 \pm 2.7 \mathrm{ab}$ \\
\hline $\begin{array}{c}\mathbf{A l C l}_{\mathbf{3}} \text {-treated group } \\
(80 \mathrm{mg} / \mathrm{kg} . \text { B.W. for } 60 \mathrm{days})\end{array}$ & $0.83 \pm 0.16 \mathrm{c}$ & $38 \pm 1.3 \mathrm{~d}$ & $21 \pm 3.1 \mathrm{a}$ \\
\hline
\end{tabular}

Number of animals 6 rats/ group.

Values were expressed as means $\pm \mathrm{SE}$.

Values with different letters are significantly different $(\mathbf{P} \leq \mathbf{0 . 0 5})$

\section{The effects of aluminium chloride on testes in rats.}

Gross pathological examination showed congested testicular at the $\mathrm{AlCl}_{3 \_}$treated groups for 30 and 60 days, other treated groups did not showed any variation compared with control group.

Light microscope examination revealed many histological alterations at $\mathrm{AlCl}_{3}$ in treated groups (testicle histological sections), these alterations include hyperemic blood vessels, interstitial edema, multiplication of interstitial Leydig cells. (Fig. 4,5).

Most of seminiferous tubules of the testis of adult male rats treated with $\mathrm{AlCl}_{3}$ showed hyperplasia of the germinal epithelium with obvious decreased in sperm bundles within tubular lumen. Desquamate and sloughing of spermatogonea into tubular lumen (Fig. 6,7,8). These changes were noticed more severly of $\mathrm{AlCl}_{3}$ treated group at dose $80 \mathrm{mg} / \mathrm{kg}$. B.W. for 30 and 60 days. More dramatic changes represented by coagultive necrosis of the spermatogenic epithelium with extensive sloughing in to tubular lumen and absence of sperm bundles with inflammation cells infiltration represented mild by lymphocytic infiltration and few macrophages were noticed at some sections at $\mathrm{AlCl}_{3}$ treated groups (40, $80 \mathrm{mg} / \mathrm{kg}$.B.W.) for 60 days. (Fig. 9,10,11).

The control groups sections showed normal seminiferous tubules, sperm bundles and interstitium. (Fig. 3) 


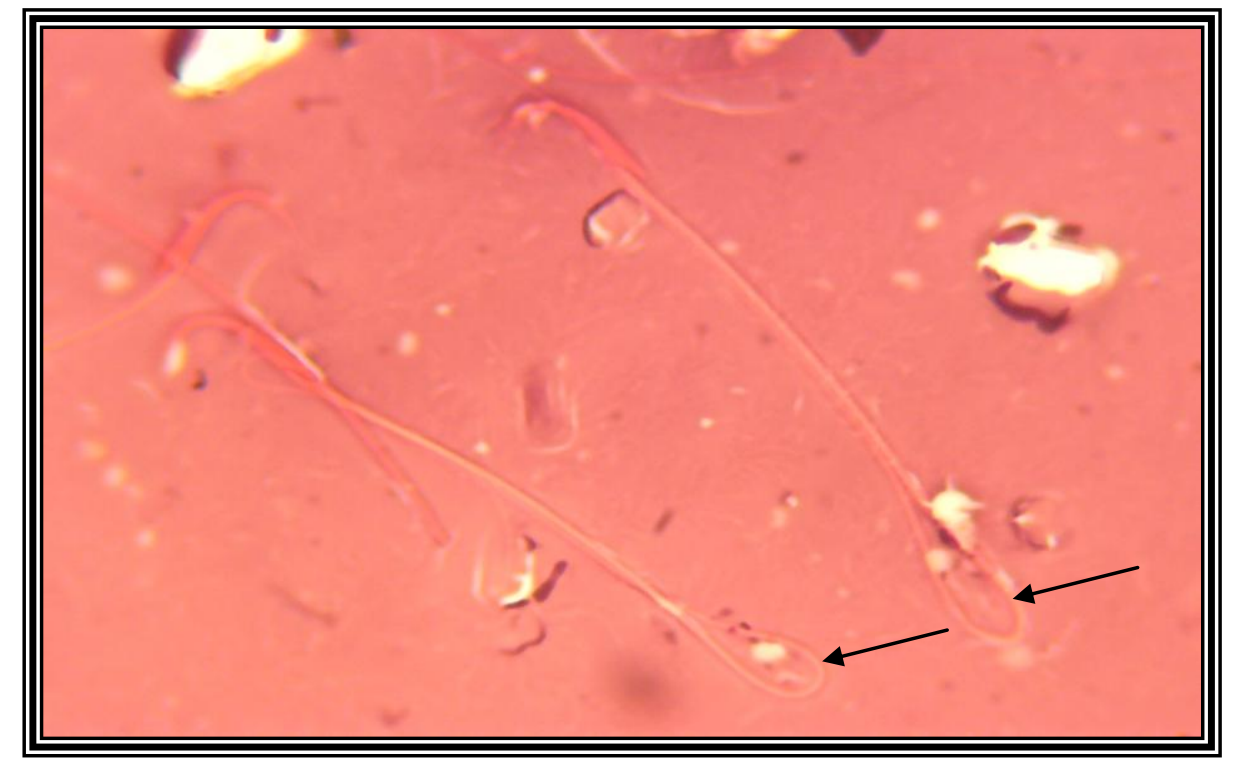

Fig.(1): Coiling tail in rats sperm treated with $\mathrm{AlCl}_{3}(80 \mathrm{mg} / \mathrm{gm} \mathrm{B.W}$.) for 30 days (eosin - nigrosin stain) $1300 \mathrm{x}$.

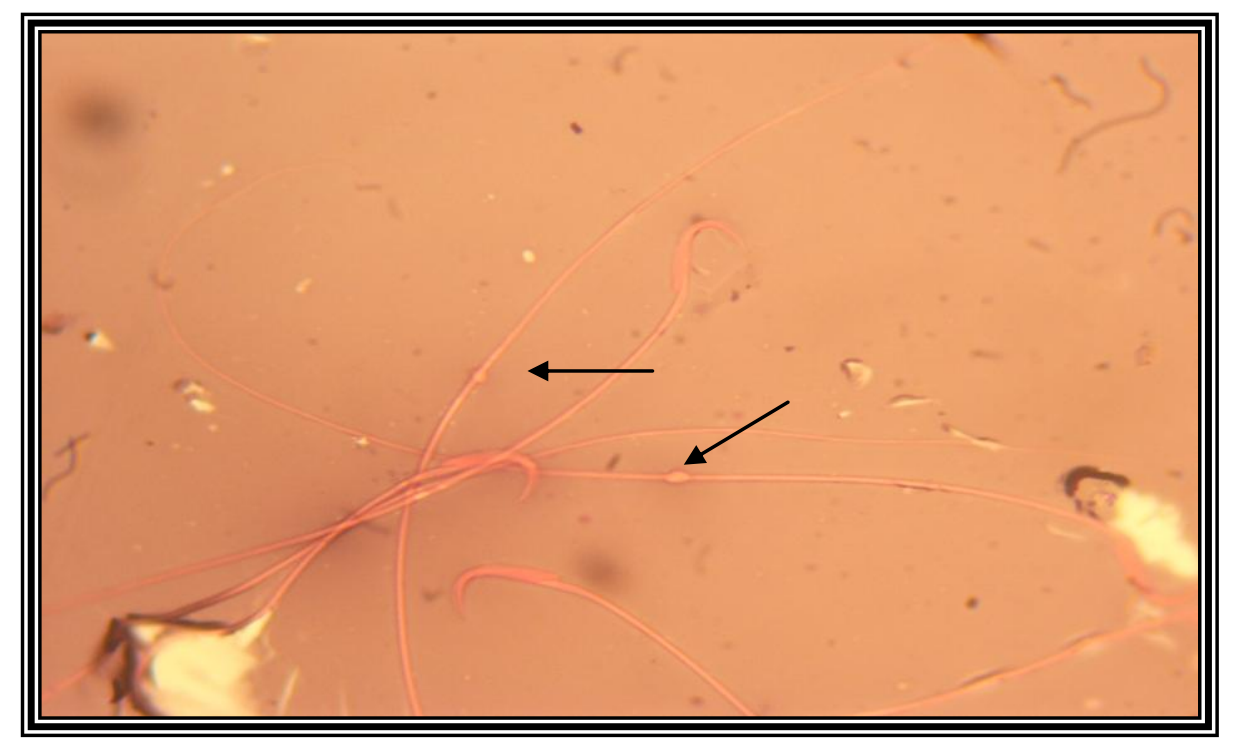

Fig.(2): Cytoplasmic droplet in rats sperm treated with $\mathrm{AlCl}_{3}(40 \mathrm{mg} / \mathrm{kg}$. B.W.) for 60 days (eosin - nigrosin stain ) $1000 \mathrm{x}$. 


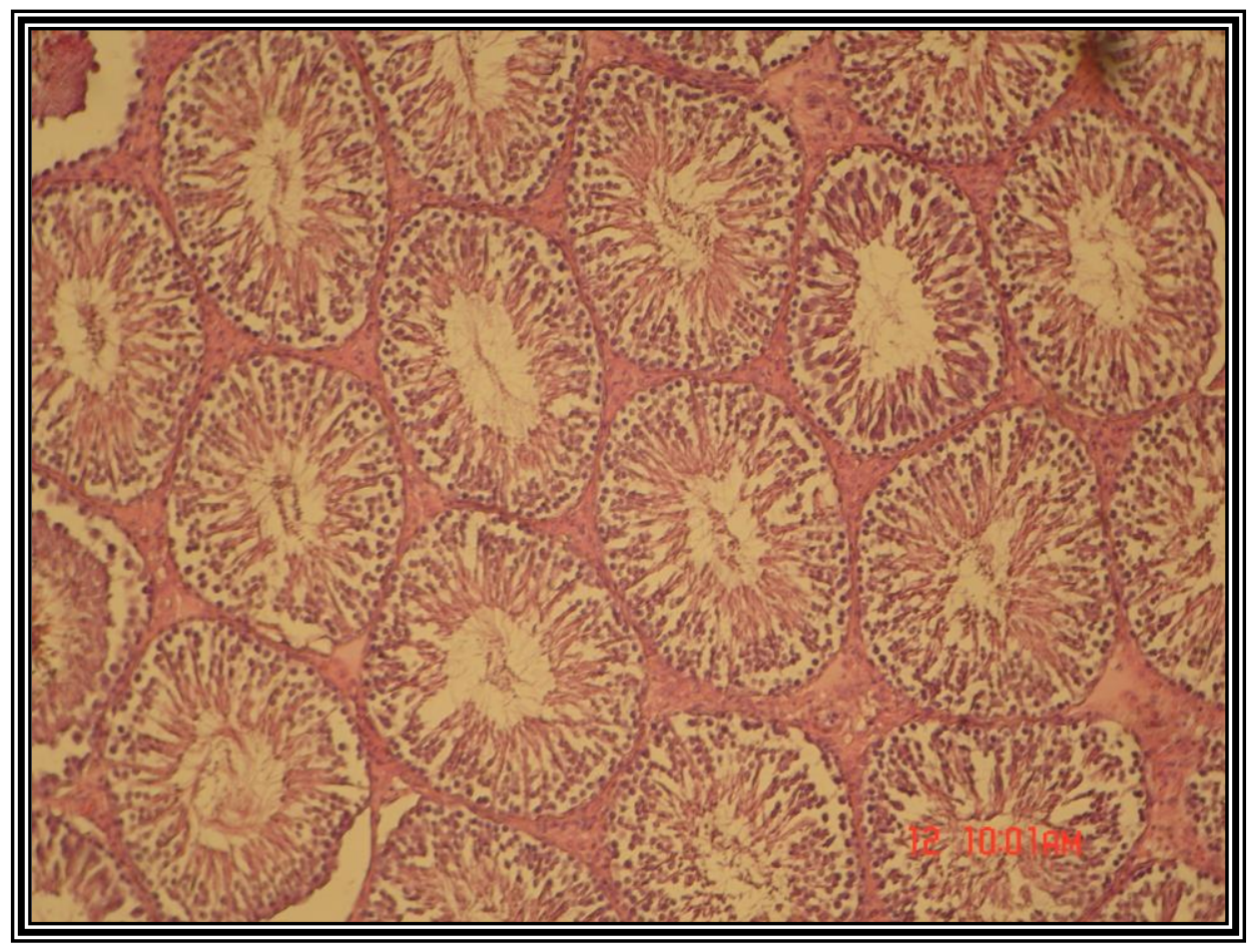

Fig. (3) :Normal histological section of testis from control group H.\&E. (Mag. $115 \mathrm{x}$ )

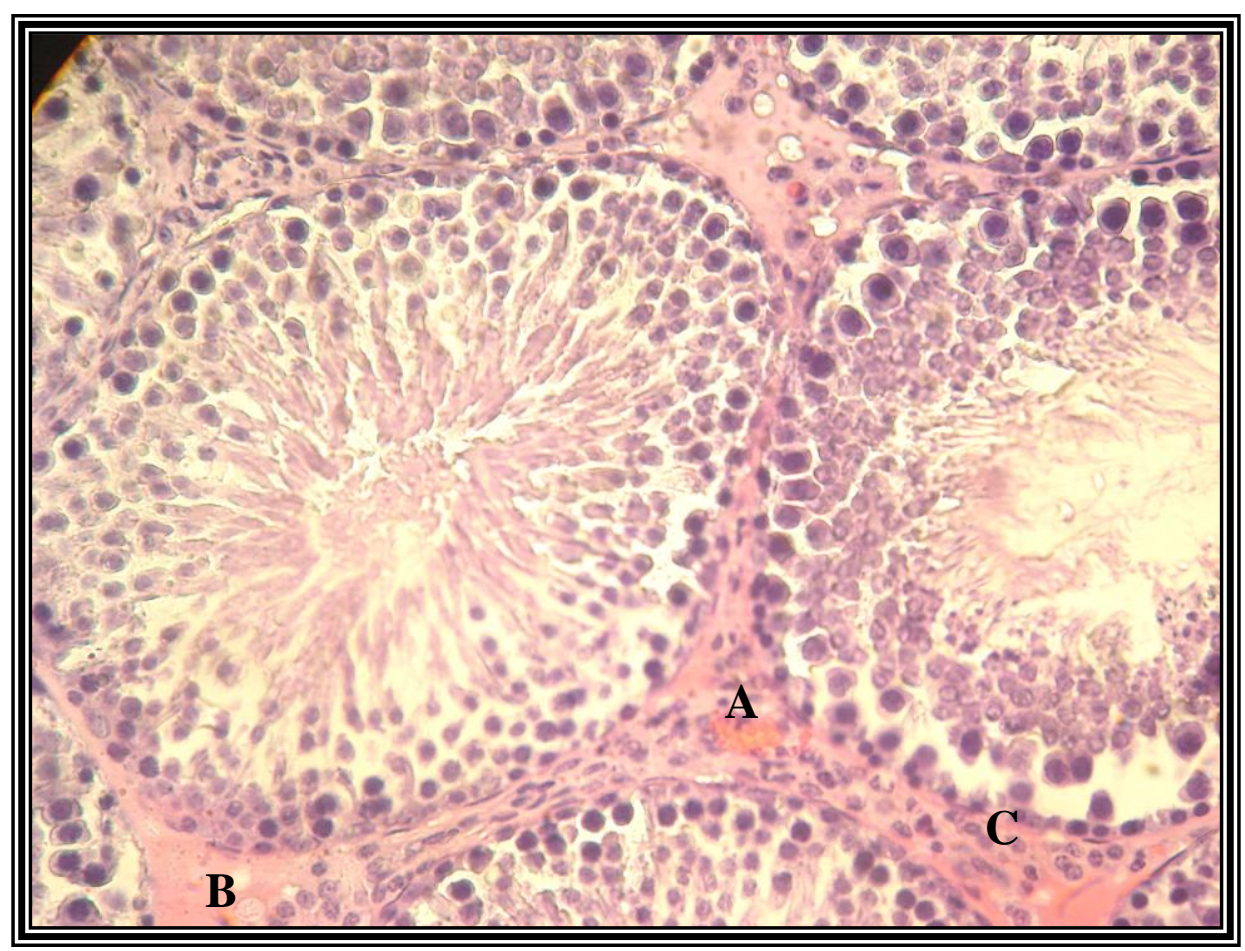

Fig. (4) : Histological section of testis from $\mathrm{AlCl}_{3}$ treated group (80 mg/kg B.W.) for 30 days showing hyperemic blood vessel (A), interstitial edema (B), Leydig cell proliferation (c). H.\&E. (Mag. $370 \mathrm{x}$ ). 


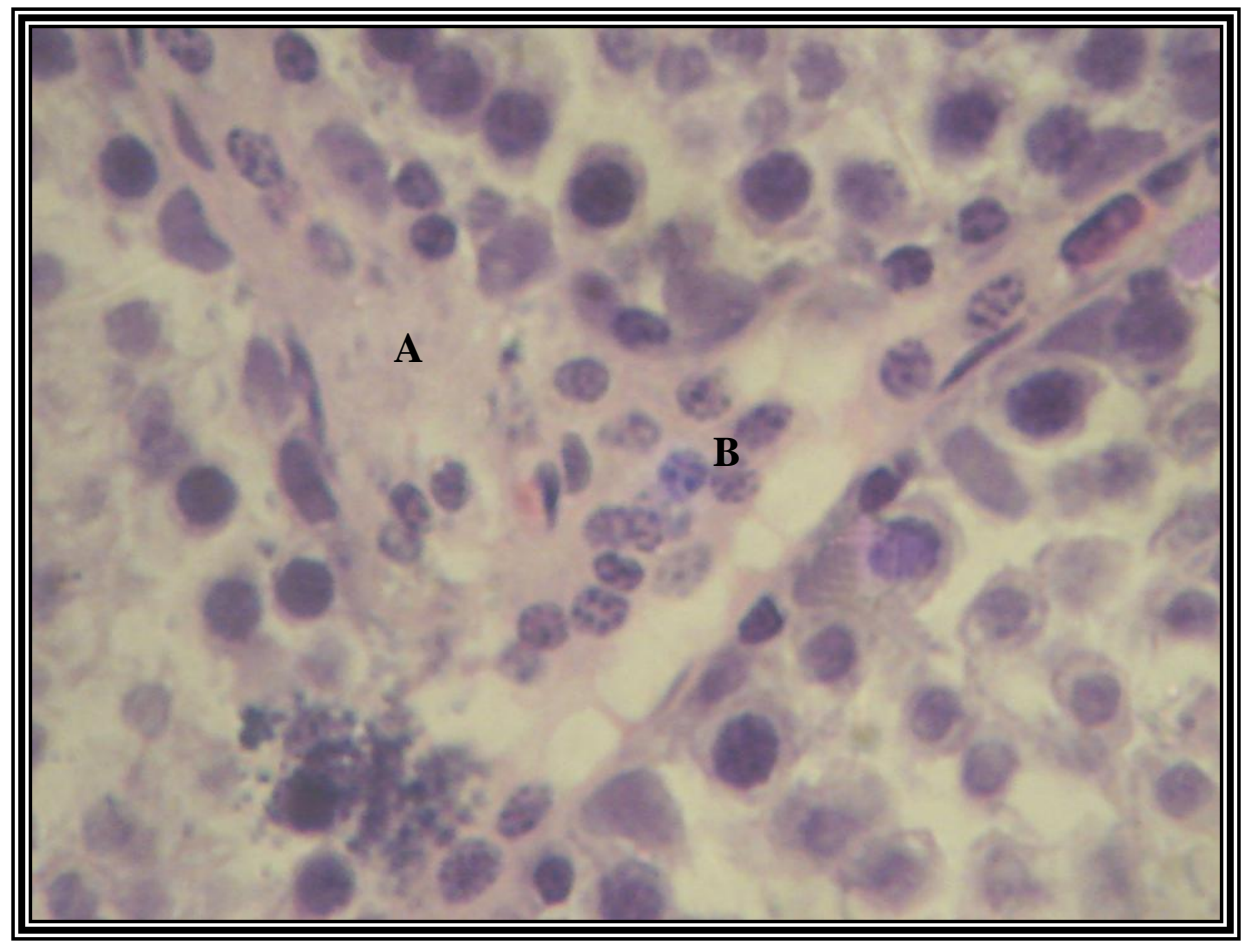

Fig. (5): Histological section of testis from $\mathrm{AlCl}_{3}$ treated group $(80 \mathrm{mg} / \mathrm{kg} \mathrm{of}$ B.W.) for 30 days showing interstitial edema (A) with Leydig cells proliferation (B). H.\&E. (Mag. 900 x).

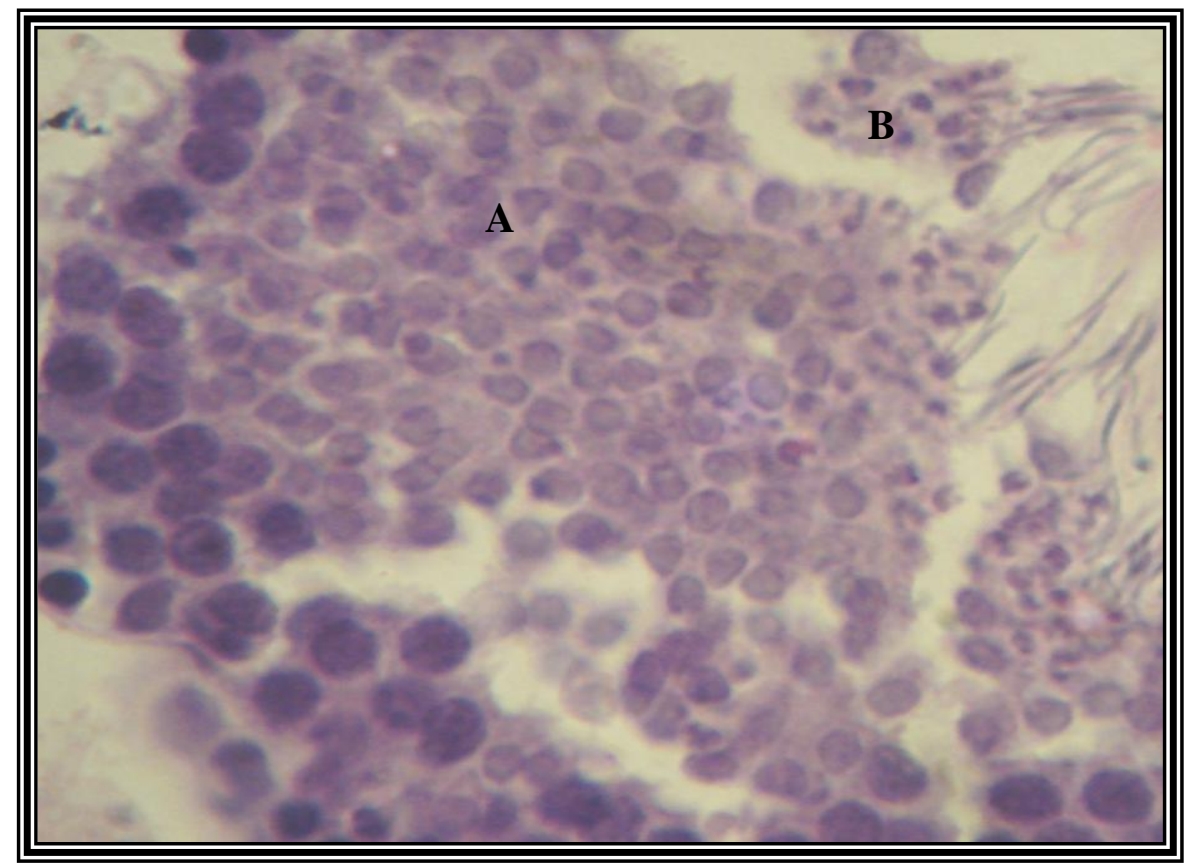

Fig. (6): Histological section of testis from $\mathrm{AlCl}_{3}$ treated group $(40 \mathrm{mg} / \mathrm{kg} \mathrm{of}$ B.W.) for 60 days showing hyperplasia (A) and sloughing (B) of germinal epithelium. H.\&E. (Mag. 760 x) 


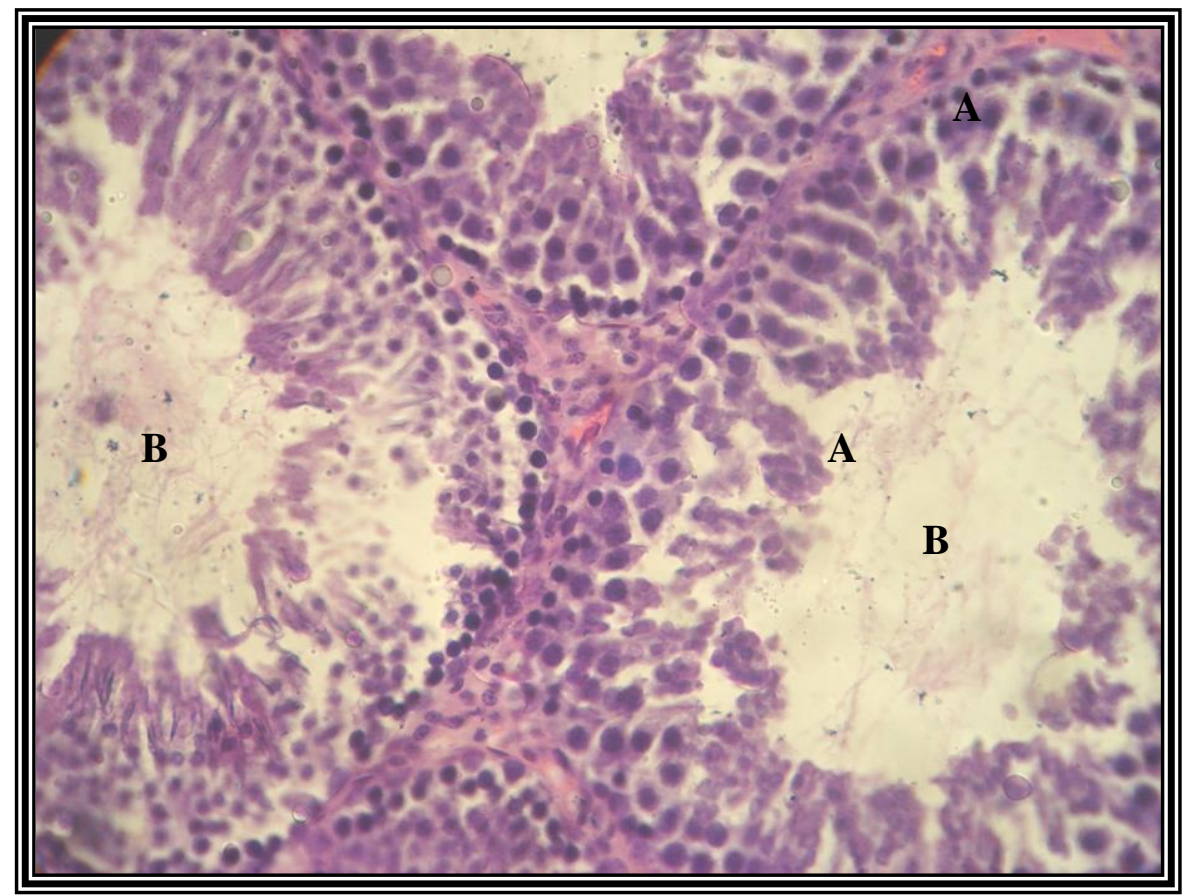

Fig. (7): Histological section of testis from $\mathrm{AlCl}_{3}$ treated group $(80 \mathrm{mg} / \mathrm{kg}$ of

B.W.) for 30 days showing sloughing of germinal epithelium (A) and oligospermia (B). H.\&E. (Mag. 370 x).

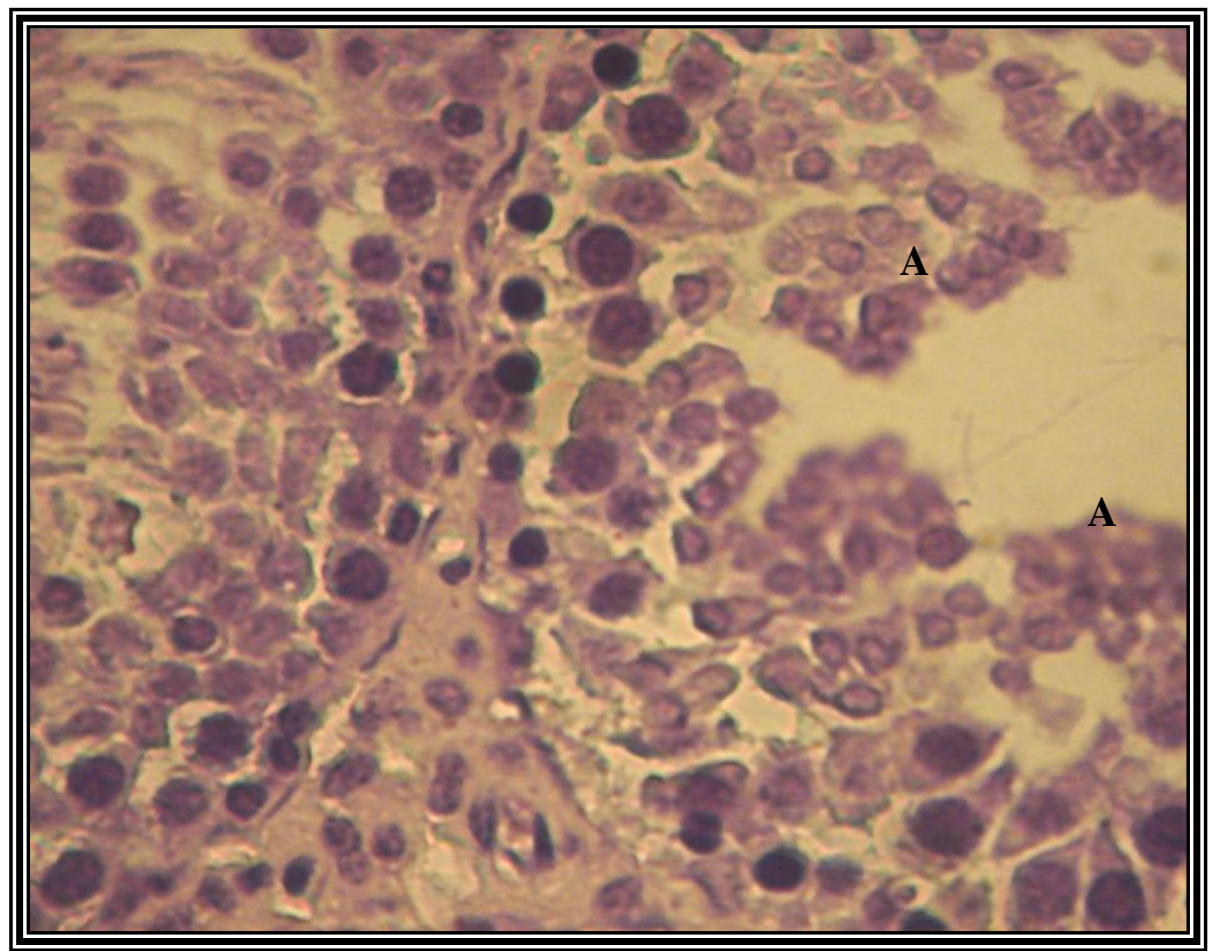

Fig. (8): Histological section of testis from $\mathrm{AlCl}_{3}$ treated group $(40 \mathrm{mg} / \mathrm{kg} \mathrm{of}$ B.W.) for 60 days showing sloughing of germinal epithelium

(A). H.\&E. (Mag. 760 x). 


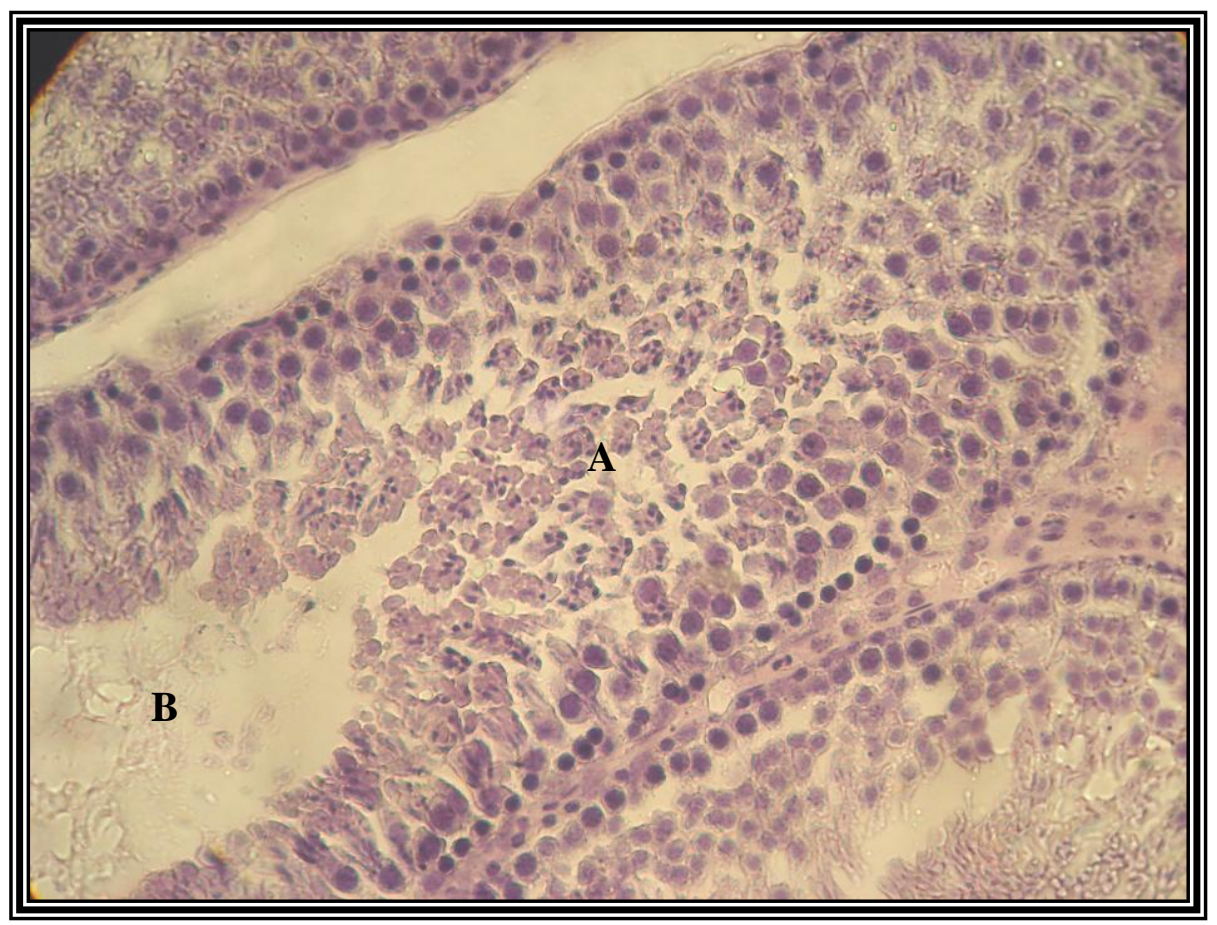

Fig. (9): Histological section of testis from $\mathrm{AlCl}_{3}$ treated group $(80 \mathrm{mg} / \mathrm{kg} \mathrm{of}$

B.W.) for 60 days showing coagulative necrosis of seminiferous epithelium with sloughing (A) and oligospermia (B). H.\&E. (Mag. 370x)

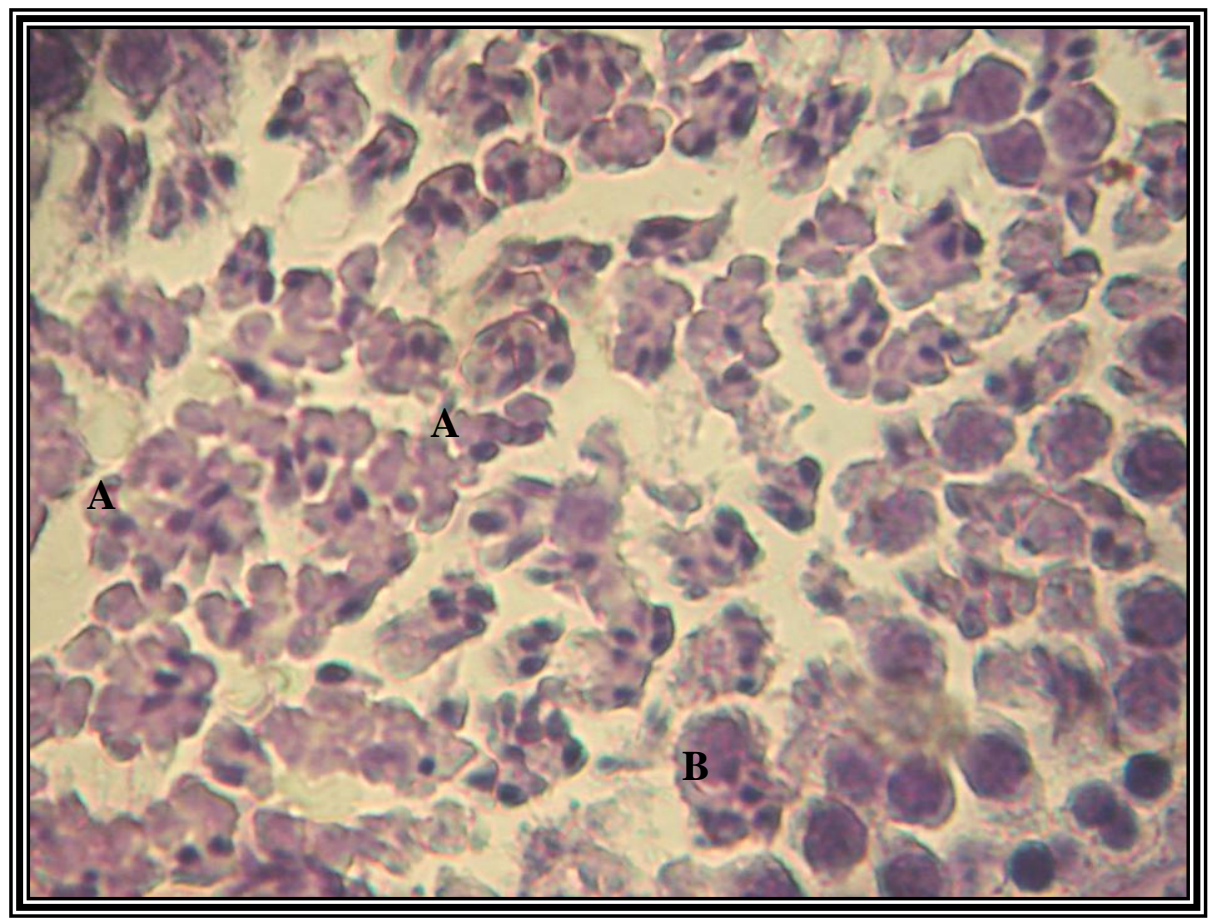

Fig. (9): Magnified capture to the same previous figure showing different stages of karioerhexis in necrotic epithelium (A) and infiltration of macrophages (B). H.\&E. (Mag. 760 x) 


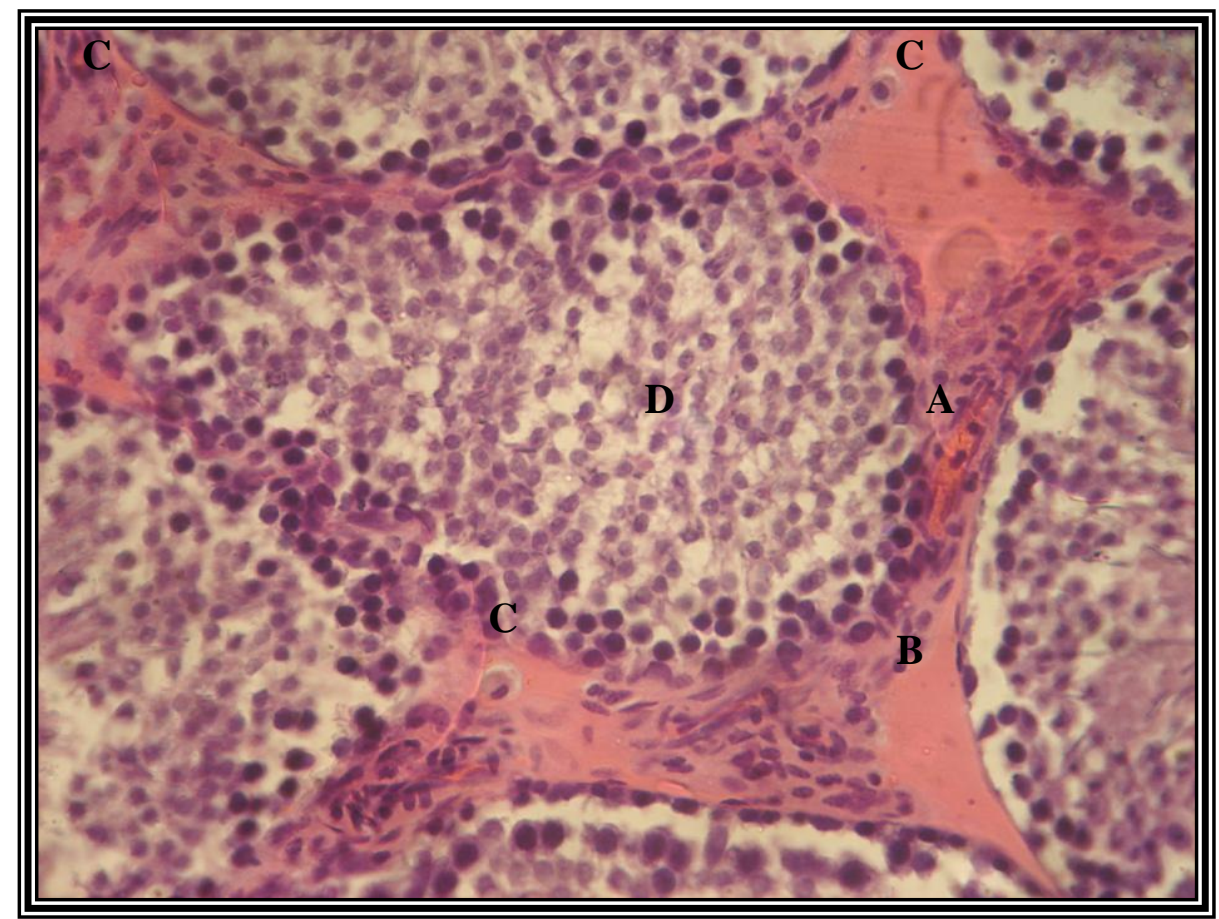

Fig. (10): Histological section of testis from $\mathrm{AlCl}_{3}$ treated group $(80 \mathrm{mg} / \mathrm{kg}$ of B.W.) for 60 days showing orchitis manifested by hyperemic blood vessels (A) profuse interstitial edema (B) inflammatory cells infiltration especially macrophages $(C)$ and extensive sloughing of seminiferous epithelium

(D). H.\&E. (Mag. 450 x ).

\section{DISCUSSION}

The present investigation revealed that the body weight was significantly reduced in males treated with $\mathrm{AlCl}_{3}(80 \mathrm{mg} / \mathrm{kg} . \mathrm{B} . W$.$) in$ comparison to control group. Similar results about the body weight is in agreement with those obtained by other investigators $(14,20)$. It appears that this reduction in body weight reflects general toxicity condition, and this will negatively affect on reproductive functions(30). The relative weights of testis and accessory sex organs decreased in animals treated with $\mathrm{AlCl}_{3}(80 \mathrm{mg} / \mathrm{kg} . \mathrm{B} . \mathrm{W}$.), similar results were obtained in others studies with $\mathrm{AlCl}_{3}$ that have reported a significant decrease in testis (13) and testicular and epididymal weights in rats (20). The reduction in the weight of testis and accessory sex organs in $\mathrm{AlCl} 3$ treated rats, which stems from reduced availability of androgens (31).

In the present study the administration with $\mathrm{AlCl}_{3}$ caused a significant decrease in both sperm counts and live sperm percentage, with associated significant increase in the percentage of abnormal sperms as compared with the control groups, which assure with those results obtained by other investigators $(14,16,20,32)$. These changes may be attributed to impairment of sperm maturation and secretory functions of epididymal cells which might be due to oxidative stress or to insufficiency of androgens. 
Recent studies showed the $\mathrm{AlCl}_{3}$ caused a significant induction of oxidative stress as evidenced by increasing thiobarbituric acid reactive substances (TBARS) levels and inhibition of superoxide dismutase and catalase activities $(16,17,33)$ and decreased glutathione(33), furthermore a significant decreased in sulphydryl groups and phosphorylase in rats treated with $\mathrm{AlCl}_{3}$ (34). So that a generation of reactive oxygen species (ROS) which may stimulates the glutathione peroxidase and inhibits catalase which result in oxidation of proteins in the terminal stages of sperm maturation (35), in addition to peroxidation of polyunsaturated fatty acids in the plasma membrane of sperm and this causes disturbances in sperm functions (36).

Ollero et al., (37) and Gil-Guzman et al., (38) showed that levels of reactive oxygen species production in semen were negatively correlated with the percentage of normal sperm forms as determined by World Health Organization (WHO)(39). Results of the present study indicates that there was a relationship between oxidative stress induced by aluminium chloride and increased the percentage of morphologically abnormal sperms. Furthermore ROS had an obvious toxic effect on tissues, it will causes histological changes on testicular tissue (40), and our observation gives an ascertainment for these results which included coagulative necrosis, sloughing and falling of seminiferous epithelium in tubular lumen, these results agreement with others studies $(14,21,22)$.

Histological observation of testis showed absence of spermatic bundles in seminiferous tubules lumen and this may results from degenerative changes of spermatogonea which affect spermatogenesis and maturation of sperms and this support our results which showing decrease in sperm count and percentage live sperm with significant increased in percentage of morphologically abnormal sperms.

Beside the role of $\mathrm{AlCl}_{3}$ in induction of oxidative stress, it's toxic effect may result from its ability to bind to cellular DNA, RNA and proteins leading to decrease their levels in different tissues(41). In addition to those harmfull mechanisms when $\mathrm{AlCl}_{3}$ enters living tissues, it will compete with nonheme iron to bind ferritin and lowering ferritin levels decreasing the ability of cells in treating iron by protective sequestration, turning the free iron to an oxidative agent (42). Those mechanisms may explain the degeneration, coagulative necrosis and epithelial sloughing in our results. Presence of interstitial edema may result from the oxidative damage of capillaries endothelial cells through interference with their membranes (43), increasing their permeability. The increase in permeability and edema may also occur in inflammatory responces because of libration of inflammatory mediators from degenerative and necrotic paranchymatus cells (44), and this may explain inflammatory cells infiltration within testicular parenchyma. 
$\mathrm{AlCl} 3$ may be implicated in the induction of sex hormones disorders, many studies recorded that $\mathrm{AlCl}_{3}$ cause a reduction in testosterone $(45,46,47)$, that resulting to reduced activities of $3 \beta$ - and $17 \beta$ - Hydroxy steroid dehydrogenase ( $3 \beta$-and 17 $\beta$-HSD) in mice testis after trearted with $\mathrm{AlCl}_{3}+$ sodium fluoride correlates with the significant accumulation of cholesterol, this in turn would reduce circulating testosterone levels and alter the metabolism of all androgen - dependent on reproductive organs in animals $(45,46,47)$. This will gives an interpreterships for the testicular sections changes which includes Leydig cells multiplication and seminiferous tubules hyperplasia in testis, which indicates testosterone biosynthesis either due to direct action on Leydig cells or through affected the function of the hypothalamas. This may result in alteration of gonadotropin releasing hormone $(\mathrm{GnRH})$ levels which may affect LH secretion from the anterior pituitary lobe (14), that stimulate Leydig cells to proliferate as a compensatory mechanism. This is supported by the study of Chinoy et al. (21), who reported a significant decline in blood testosterone in mice. Disturbance in testosterone and LH levels after administration of $\mathrm{AlCl}_{3}$ suggested in the premature release of spermatids that may cause the reduce testicular and epididymal sperm counts. We conclude that $\mathrm{AlCl}_{3}$ adversely affects the reproductive functions of male rats, probably by virtue of suppression of androgen biosynthesis or oxidative stress.

\section{ACKNOWLEDGEMENTS}

This study was supported by the college of Veterinary Medicine, University of Mosul, and authers acknowledge the assistance of the workers in animal house, in the college. 


\section{REFERENCES}

1) MSDS database record for aluminium chloride solution (Dow Chemical Canada Inc). Date of MSDS :13/10/1994.

2) Havas, M. and Jaworski, J. F. Aluminium in the Canada Enviromnent, National Research Council of Canada, Ottawa, Canada (1986).

3) Yousef, M. I. Aluminium_induced changes in hematobiochemical parameter, lipid peroxidation and enzyme activities of male rabbits: protective role of ascorbic acid. Toxicol.199:47-57 (2004).

4) Grams. G. W. Aluminium compounds: aluminium halides and aluminium nitrate: aluminium chloride. In: Kirk_Othmer encyclopedia of chemical technology. $4^{\text {th }}$ ed. Vol 2. John Wiley and Sons: 281-288 (1992).

5) Cannata, J., Briggs, J., Junor, R. and Fell, S. Aluminium hydroxide intake real risk of aluminium toxicity. Brit. Med. J. 286: 1937-1938. (1983).

6) Lione, A. Aluminium toxicity and aluminium containing medication. J. Pharmacol. Therapy, 29: 255-285. (1985).

7) Kachny, W., Hegg, A. and Alfrey, A. Gastrointestinal absorption of aluminium from aluminium containing antacids. New Engl. J. Med. 296: 1389-1390. (1997).

8) ATSDR (Agency for Toxic Substances and Disease Registry). Toxicological profile for aluminium. U.S. Department of Health and Human Services. Public Health Service (1990).

9) Ochmanski, W. and Barabasz, W. Aluminium occurrence and toxicity for organisms. Przegl. Lek. 57:665-668 (2000).

10) Maksoud, H. A., Fararh, K. M., Ghanem, M. M. and Fat_Hallah, S, M. Effects of aluminium administration on brain and liver enzymes activities and trace elements concentration in rats with evaluation of the protective role of vitamin A and Riboflavin. Vet. Med. J. Giza 53 (2): 423-437 (2005).

11) Graves, A. B., White, E., Koespsell, T. D., Relfler, B. V., Belle, G. $\mathrm{V}$. and Larson, E, B. The association between aluminium containing products and Alzheimer`s disease. J. Clin. Epidemiol. 43:35-44 (1990).

12) World Health Organization (Geneva). Environmental health criteria 194: Aluminium. Printed in Finland 97/PLL/11539- Vammada 5000: WHO, p 1-282 (1997). 
13) Bataineh, H., Al- Hamood, M. H. and Elbetieha A. M. Assessment of aggression, sexual behavior and fertility in adult male rat following long - term ingestion of four industrial metals salts. Hum. Exp. Toxicol. 17 (10) : 570-576 (1998).

14) Mayyas, I., Elbetieha, A. and Khamas, W. A. Evaluation of reproductive and fertility toxic potentials of aluminium chloride on adult male mice. Journal of animal and Veterinary Advances. 4(2): 224: 233 (2005).

15) Malekshah, A. K., Torabizadeh, Z. and Naghshwar, F. Developmental toxicity of aluminium from high doses of $\mathrm{ALCL}_{3}$ in mice. The journal of Applied Research. Vol. 5 (4) : 575-579. (2005).

16) Yousef, M. I., El_Morsy, A. M. and Hassan, M. S. Aluminium induced deterioration in reproductive performance and seminal plasma biochemistry of male rabbits: protective role of ascorbic acid. Toxicology 215 (1-2): 97-107 (2005).

17) Yousef, M. I., Kamel, K. L., El_Demerdash, F. M. An in vitro study on reproductive toxicity of aluminium chloride on rabbit sperm: the protective role of some antioxidants. Toxicology 239(3): 213-223 (2007).

18) Chinoy, N. J., Bhattacharya, S. E. Effect of single dose of aluminium chloride on some reproductive organs and fertility in male mice. India. J. Environ. Toxicol. 6 :10-13 (1996).

19) Chinoy, N. J., Bhattacharya, S. E. Effects of chronic administration of aluminium chloride on reproductive functions of testis and some accessory sex organs of male mice. India. J. Environ. Toxicol. 7:1217 (1997).

20) Liobet, J., Colomina, M., Sirvent, J. Domingo, J. and Corbella, J. Reproductive toxicology of aluminium in male mice. Fundam. Appl. Toxicol. 25 (1): 45-51 (1995).

21) Chinoy, J., Sorathia, P. and Jhala, D. Flouride + Aluminun induced toxicity in mice testis with giant cells and its reversal by vitamin $\mathrm{C}$. J. Fluride, 38 (2): 109-114 (2005).

22) Khattab, F. K. I. Histological and ultrastructural studies on the testis of rat after treatment with aluminium chloride. Australian Journal of basic and applied Sciences 1(1): 63-72 (2007).

23) Guo, C., Huang, C., Chiou,y. and Hsu, G. Alteration of trace element distribution and testis ACE activity in mice with high peritoneal aluminium. J. Biol. Trace. Elem. Res. 86(2):145-157 (2002). 
24) Reis, A., Totsch, M., Shennid, H., Ofner, D., Serrick, C., Jamjoom, A., Chikhani, N., Mikuz, G. and Margreiter, R. Bronchoalveolar lavage: results of sequential selective techniques in viable murines. Am. J. Respir. Crit. care Med. 150(2): 547-550 (1994).

25) Al_Sanafi, A.E.U. The effect of multiple administration of diazepam on the reproductive characters in laying hens. $\mathrm{Ph}$. D. thesis, College of Veterinary Medicine, University of Baghdad (1990). (In Arabic ).

26) Sakamoto, J. Hashimoto, K. Reproductive toxicity of crylamide and related compounds in mice: Effect on Fertility and sperm morphology. Arch. Toxicol. 59: 201-205 (1986).

27) Al_Sadi, H. A. Artificial in semination. Vol. 1. Ministry of Higher Education, University of Baghdad (1989). (In Arabic).

28) Luna, L. G. Manual of histologic staining methods of the armes forces institute of pathology. $3^{\text {rd }}$ ed. McGraw-Hill book company, New york (1968).

29) Steel, R. O. D., Torrie, J.I.I. Principles and produces of statistics. New York: Macgraw _till Book Company. Inc. 76 (1960).

30) Chapin, R. E. D., Gulati, D. K., Barnes, L. H. and Teague, J. L. The effects of feed restriction on reproductive function in Sprague dawley rats. Fun. Appl. Toxicol. 20: 23-29 (1993).

31) Coffey, D. S. Androgen action and the sex accessory tissues. In the physiology of reproduction (Knobil, E. and Neil, J.D. Eds.) Raven Press, New York: 1081-1119 (1988).

32) Krasovskii, G. N., Vasulovich, L. Y. and Charie, O. G. Experimental study of biological effects of lead and aluminium following oral administration. Environ. Health. Perspect. 30:47-51(1979).

33) Sharma, P., Ahmad Shah, Z., Kumar, A., Islam, F. and Mishra, K. P. Role of combined administration of tiron and glutathione against aluminium - induced oxidative stress in rat brain. $\mathbf{J}$ Trace Elem Med Biol; 21 (1):63-70 (2007).

34) El-Demerdash, F. M. Antioxidant effect of vitamin $E$ and selenium on lipid peroxidation, enzyme activities and biochemical parameters in rats exposed to aluminium. J. Trace. Elem. Med. Biol. 18(1):113121 (2004).

35) Maiorino m M., Ursini, F. Oxidative stress, spermatogenesis and fertility. Biol. Chem. 383: 591-597 (2002).

36) Sanocka, D., Kurpisz, M. reactive oxygen species and sperm cell. Reprod Biol Endocrinol 2: 12 (2004). 
37) Ollero, M., Gil-Guzman m E., Lopez, M. C., et al. Characterization of subsets of human spermatozoa at different stages of maturation: implications in the diagnosis and treatment of male infertility. Hum Reprod: 16: 1912-1921 (2001).

38) Gil-Guzman, E., Ollero, M., Lopez, M. C., Sharma, R. K., Alvarez, J. G., Thomas, A. J. and Agarwal, A. Differential production of reactive oxygen species by subsets of human spermatozoa at different stages of maturation. Hum Reprod; 16: 1922-1930 (2001).

39) World Health Organization (WHO). WHO laboratory manual for the examination of human semen and sperm-cervical mucus interaction. $4^{\text {th }}$ ed. Cambridge University Press; 1999. (cited by Saleh Ra, Agarwal A. Oxidative stress and male infertility: From Research Bench to Clinical Practice. J Androl ; 23(6) : 737-752 (2002).

40) Ishihara, M., Itoh, M., Miyamoto, K., Suna, S., Takeuchi, Y., Takenaka, I. and Jitsunari, F. Spermatogenic disturbance induced by di-(2-ethylhexyl) phthalate is significantly prevented by treatment with antioxidant vitamins in the rat. Int J Androl; 23:85-94 (2000).

41) Fyiad, A. A. Aluminium toxicity and oxidative damage reduction by melatonin in rats. J Appl Sc Res; 3: 1210-1217 (2007).

42) Han, J. and Dunn, M. A. Effect of dietary aluminium on tissue nonheme iron and ferritin levels in the chick. Toxicology 142: 97109 (2000).

43) Farga, C. G., Oteiza, P. I. and Golub, M. S. Effects of aluminium on brain lipid peroxidation. Toxicol; 51: 213-219 (1999).

44) Kumar, V., Cortan, R. and Robins, M. D. Acute and chronic inflammation. Basic pathology. $6^{\text {th }}$ ed. WB Saunders Company. Philadelphia: 25-46 (1997).

45) Chinoy, N. J. and Bhattacharya, S. Effects of a single dose of aluminium chloride on some reproductive organs and fertility in male mice. Indian J Environ Toxicol; 16(1): 10-13 (1996).

46) Chinoy, N. J. and Bhattacharya, S. Effects of chronic administration of aluminium chloride on reproductive functions of testis and some accessory sex organs of male mice. Indian J Environ Toxicol; 7(1): 12-17 (1997).

47) Memon, M. R. and Chinoy, N. J. Effect of sodium fluoride and/or aluminium chloride treatments on some organs of male mice (abstract). XVI ${ }^{\text {th }}$ National Symposium on Reproductive Biology and Comparative Endocrinology; 1998 Jan 21-22; University of Kerala, Trivandrum, India. 